\title{
INNOVATIVE METHOD OF NITRIFICATION AND DENITRIFICATION ON THE EXAMPLE OF WASTEWATER TREATMENT PLANT OF KOLOMYIA
}

\author{
Department of Hydraulic and Water Engineering, \\ Lviv Polytechnic National University, \\ ihor.y.popadiuk@lpnu.ua
}

(C) Popadiuk I., Matlai I., Pitsyshyn B., Sydor T., 2021

The article is devoted to the unsatisfactory operation of biological wastewater treatment plants. At present in Ukraine there are no developments of equipment and devices to ensure the operation of treatment facilities using the technology of nitridenitrification of deep wastewater treatment from nitrogen and phosphorus compounds. The analysis of the equipment of biological treatment systems nitri treatment plant - denitrifier, clarifier tanks is carried out. At the same time, the standards of the degree of purification of both Ukraine and the European Union were taken into account. On the example of treatment facilities in Kolomyia, Ivano-Frankovsk region, modern schemes of biological wastewater treatment for the removal of nitrogen and phosphorus have been proposed, namely, the reequipment of single-corridor aerotanks into bioreactors of nitridenitrifiers by creating zones with different oxygen conditions in their volume.

Keywords: wastewater, aeration tank, nitrification, denitrification, clarifier tank, active sludge.

\section{Formulation of the problem}

A large amount of wastewater treatment plants in Ukraine face unsatisfactory operation of biological wastewater treatment facilities (Blyashyna et al., 2018). The main measure to improve the quality of treatment at treatment plants is to transfer them to the technology of nitrogen and phosphorus removal (Shved et al., 2014). The cost and efficiency of this work largely depend on how correctly the technological calculations of new technologies will be carried out. In recent years, new technological schemes for biological treatment of urban wastewater have been developed, which allow removing nutrients from urban wastewater.

At the same time, the standards of the degree of purification of both Ukraine and the European Union must be taken into account. Despite the fact that the quality standards of wastewater treatment in Ukraine (biological oxygen demand (BOD), suspended solids) are much stricter than EU standards.

Today in Ukraine there are no certified developments of equipment and devices to ensure the operation of treatment facilities using the technology of nitridenitrification of deep purification of wastewater from nitrogen and phosphorus compounds (Shved et al., 2014).

\section{Relevance of research}

Unsatisfactory operation of treatment plants in Kolomyia, Ivano-Frankivsk region led to the search for a solution to this problem.

According to the accepted classification (DBN V.2.5-75:2013, 2013), at present, the municipal wastewaters of Kolomyia are classified as low-concentrated in terms of the degree of pollution by $\mathrm{BOD}_{20}$ (twenty-day BOD) and suspended solids $\left(\mathrm{BOD}_{20}=42 \times 1.5=63 \mathrm{mg} / \mathrm{l}\right)$. 
However, the concentration of ammonium nitrogen in urban wastewater entering to the treatment plant is quite high relative to the organic pollutant of the wastewater. Thus, with the optimal ratio of $\mathrm{BOD}_{20}: \mathrm{N}($ nitrogen):P(phosphorus) recommended for biological wastewater treatment $-100: 5: 1$, the actual ratio in this case is 100:44:9.

It is the very low values of substrate (organic) loads on activated sludge, and the design features of clarifier-aerotanks do not allow increasing the hydraulic capacity of biological treatment facilities, because it will lead to almost complete removal of suspended activated sludge from the clarifier zone of aeration tanks.

At the current capacity of Kolomyia treatment plants $\left(20.000 \mathrm{~m}^{3} /\right.$ day), approximately $30 \%$ of wastewater without biological treatment is discharged from the treatment complex, which violates the established regulations and current standards of maximum allowable discharges. The existing treatment facilities are now technically outdated.

The operation of biological wastewater treatment plants is based on the traditional technology of biological treatment that is not able to ensure the established high standard requirements for the quality of treatment, as it is designed for predominant removal of oxygen-oxidizing organic substrate by suspended activated sludge and does not provide the possibility of deep extraction of nitrogen and phosphorus compounds from wastewater.

In addition, the features of the nature of the pollution of incoming wastewater, in particular, a low concentration of organic pollutants, a significant imbalance in the ratio of the organic component of pollution and the concentration of nitrogen compounds, and significant fluctuations in the concentration of pollutants during the day negatively affect the living conditions of activated sludge of aeration tanks and its sedimentation properties.

After all, as is known, in bioconstructions to which low-concentration BSC effluents are fed, activated sludge is poorly deposited in secondary settling tanks and removed from treatment plants, which makes it impossible to maintain the required dose of sludge in the aeration zone of aeration tanks and leads to systemic disturbances in wastewater treatment process, which, indicates the low efficiency of wastewater treatment at the existing treatment complex for almost all standard indicators.

\section{Formulation of the purpose and objectives of the article}

The main purpose of the article is to analyze the existing in the world practice technological schemes for the removal of nitrogen and phosphorus and to propose for the complex deep purification of wastewater from organic and biogenic pollution the scheme used at the treatment facilities in Kolomyia, Ivano-Frankivsk region.

\section{Analysis of recent research and publications}

Today, various methods and technological schemes are used to remove nitrogen and phosphorus from wastewater. In particular, there are schemes of biological treatment, which provide for the possibility of individual removal of nitrogen or phosphorus, or simultaneous removal of these elements (Chandran \& Smets, 2005; Akın \& Ugurlu, 2003; Peng et al., 2021; Wu et al., 2021).

In general, the technology of wastewater treatment from nitrogen and phosphorus assumes for the presence of three main elements (Henze et al., 2008):

- zone of anaerobic treatment of a mixture of wastewater and activated sludge;

- $\quad$ anoxide zone for the denitrification process;

- oxide (aerobic) zone for the nitrification process.

In the zone of anaerobic treatment under the action of special microorganisms contained in the activated sludge, enzymatic hydrolysis of organic contaminants and phosphorus removal occurs.

In the anoxide zones, the process of reduction of nitrates to gaseous nitrogen (denitrification) takes place.

In the last, aerobic zone, the process of nitrification and removal of phosphates from wastewater takes place (Vendramelli et al., 2017). 
In the world's engineering practice, a significant number of schemes are used to organize the technological process of removal of nutrients (nitrogen, phosphorus) (Sedlak, 2018). Among the most commonly used are: anaerobic-oxide process scheme (A/O); anaerobic-anoxide-oxide process scheme (AA/O); Ludchak-Oettinger process scheme; UCT process scheme (University of Cape Town); JHB process scheme (Johannesburg); Bardenpho process scheme.

Anaerobic oxide process scheme (A/O). One of the simplest schemes of removal of nitrogen and phosphorus compounds from wastewater is the scheme of anaerobic-oxide process (Fig. 1) (Xu et al., 2014). According to this scheme, the wastewater entering the purification is mixed with the return activated sludge and fed to the anaerobic reactor. After the anaerobic reactor, the wastewaters are treated under aerobic conditions and enter the secondary clarifier.

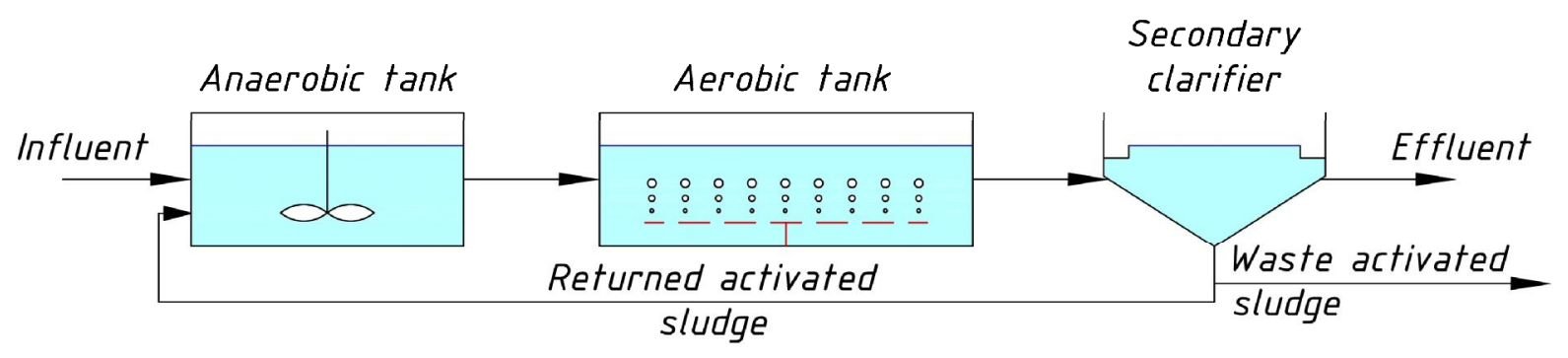

Fig. 1. Technological scheme of the A/O process

The advantage of the $\mathrm{A} / \mathrm{O}$ scheme is its simplicity in construction and operation and relative cheapness. On the other hand, this scheme has a number of disadvantages, which include: a small effect of denitrification, as only a small amount of nitrates and nitrites formed during nitrification, return to the beginning of the scheme as part of the recirculating activated sludge; nitrates and nitrites present in the reverse activated sludge slow down the dephosphating process. Therefore, with such a wastewater treatment scheme, the effect of removing phosphorus compounds is only $70 \%$.

Ludchak-Oettinger $(\mathrm{LO})$ process scheme. This scheme wastewater treatment is regulated by the German design standard ATV-131E (ATV-DVWK Standard A 131E, 2000). The essence of the MLE method is to increase the efficiency of the denitrification process as a result of an internal recirculation system, in which part of the sludge mixture from the end of the nitrifiers returns to the beginning of the denitrifier (Fig. 2). This scheme is more efficient than the $\mathrm{A} / \mathrm{O}$ scheme and with a high degree of internal recirculation, it is possible to achieve the efficiency of nitrogen extraction from wastewater at the level of 200-500\%. However, this degree of recycling will require additional high operating costs.

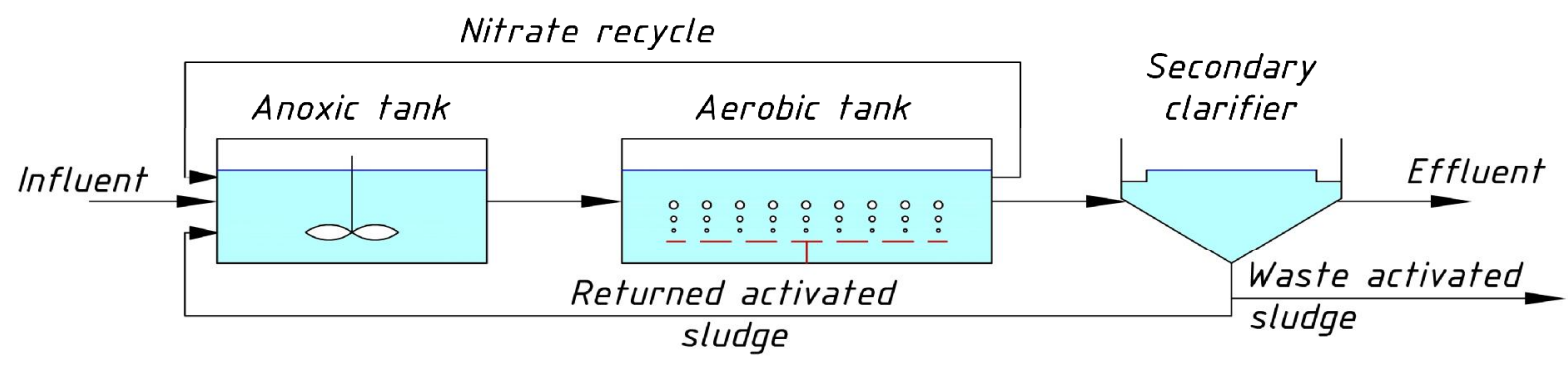

Fig. 2. Technological scheme of the Ludchak-Oettinger process

Anaerobic-anoxide-oxide process (AA/O) scheme. The technological scheme AA/O (Xie et al., 2016) is a modification of the Ludchak-Oettinger process scheme. The difference is that at the beginning of the AA/O scheme, an anaerobic zone is established, into which recirculated activated sludge is fed (Fig. 3). 


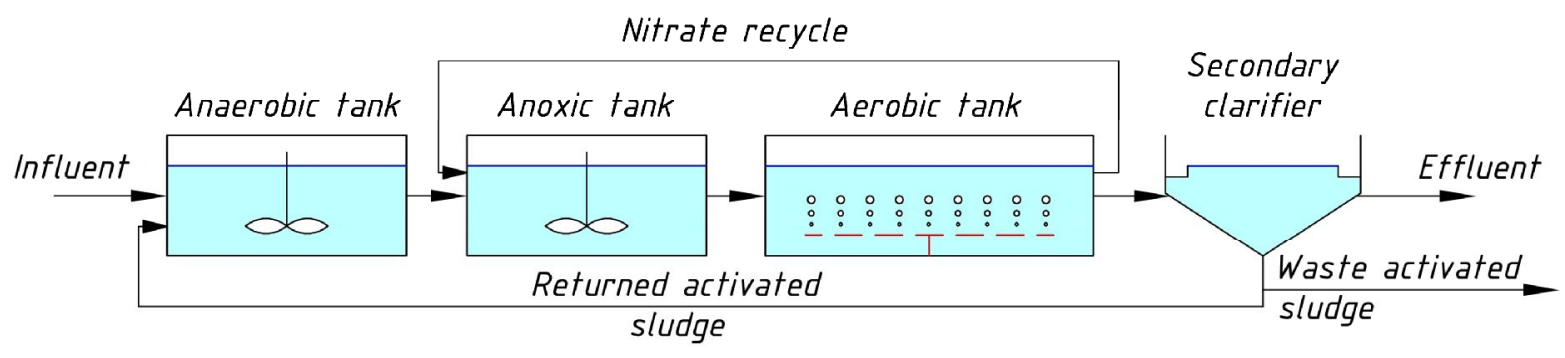

Fig. 3. Technological scheme of the AA/O process

This scheme allows both the denitrification process and the dephosphating process.

The disadvantage of the AA/O scheme is the low efficiency of biological removal of phosphorus, because the anaerobic zone receives activated sludge, which has not undergone the process of denitrification. The negative effect on the denitrification process in the anoxide zone can also be caused by the presence of dissolved oxygen in the recycled nitrate-containing mixture. Therefore, they try to pre-denitrify the return sludge.

Alternating denitrification process scheme. The technological scheme of the process of alternating denitrification (Henze et al., 2008; HJ 576-2010, 2010) is shown in Fig. 4.

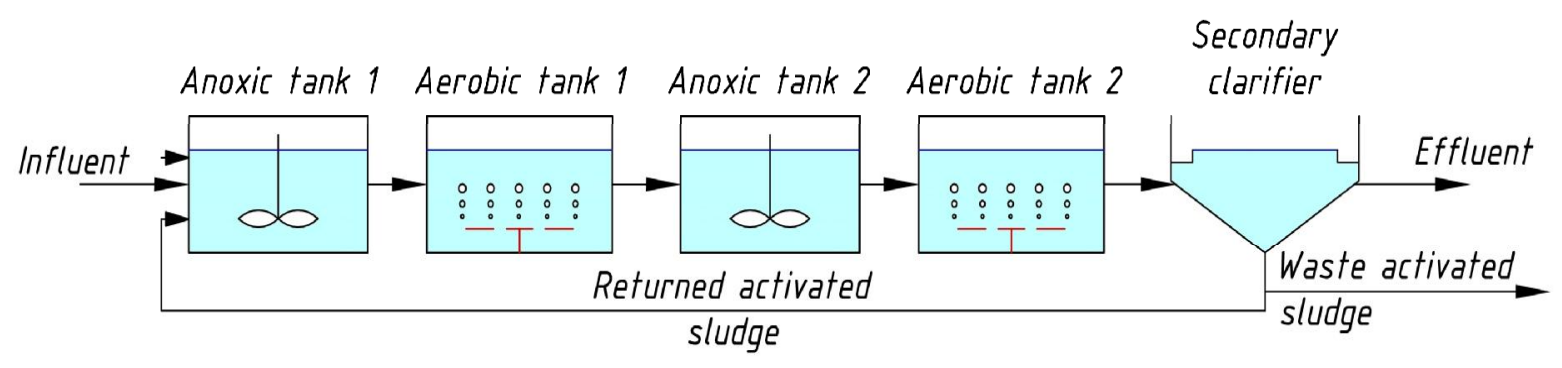

Fig. 4. Technological scheme of alternating denitrification process

This scheme of the wastewater treatment process from nitrogen and phosphorus compounds assumes that the contaminated water first enters the anoxide zone, where the denitrification process takes place. Wastewater used for denitrification is supplied to the same zone as a carbon source. The next aerobic stage, in which there is a decrease in the content of organic pollutants in wastewater, and nitrification. A mixture of sludge from this zone, which contains nitrates, is fed to the next anoxide zone of denitrification. The process ends with an aerobic zone, in which nitrification and partial dephosphatation are carried out.

Bardenpho process scheme. The Bardenpho (Barnard Denitrification Phosphorus) wastewater treatment process was developed by James Barnard in the 1970s. This is a four-stage biological process in which treatment occurs by sequential passage of wastewater through the denitrifier and nitrifier of the first degree and denitrifier and nitrifier of the second degree (Fig. 5).

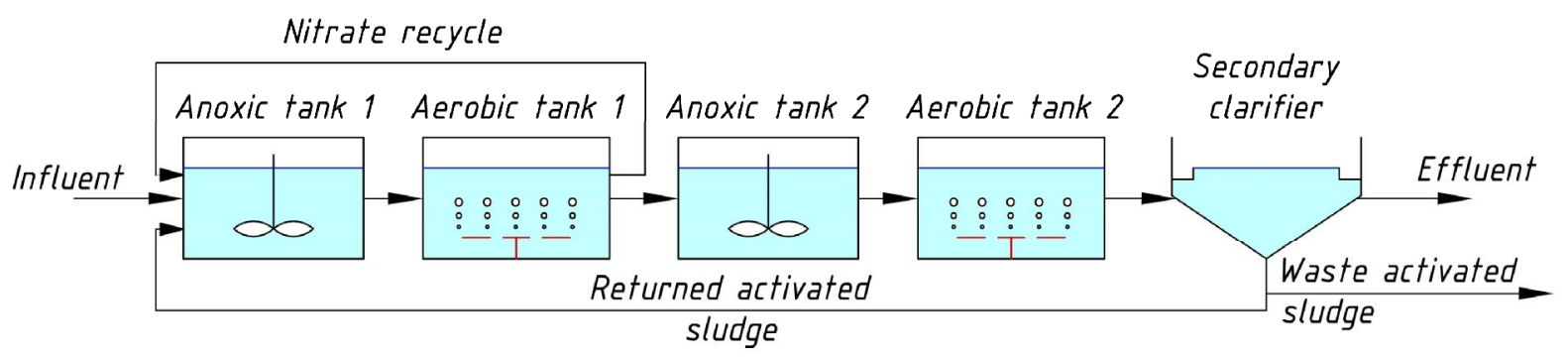

Fig. 5. Technological scheme of the Bardenpho process

This scheme also involves the recirculation of the sludge mixture from the end of the first nitrifier to the beginning of the structures (Dursun et al., 2012). The advantage of the Bardenpho scheme is the 
possibility of wastewater treatment with total nitrogen up to concentration of $2.5-5.0 \mathrm{mg} / \mathrm{l}$. One of the main disadvantages of this process is the large number of required tanks, which significantly increases the cost of construction and operation.

Modified Bardenpho process scheme. The difference between the modified method and the previous one is the anaerobic zone before the four-stage process (Fig. 6) (Banayan Esfahani et al., 2019).

The anaerobic zone, which appears in the modified scheme, promotes the removal of phosphorus from wastewater. Simultaneous removal of nitrogen and phosphorus from wastewater is the main advantage of the modified process over the conventional Bardenpho process.

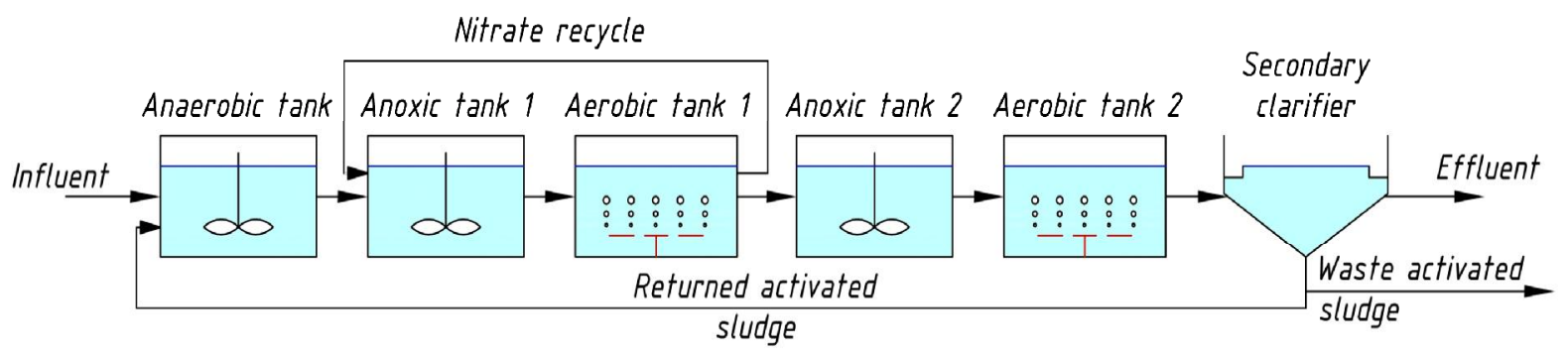

Fig. 6. Technological scheme of the modified Bardenpho process

\section{JHB (Johannesburg) process scheme.}

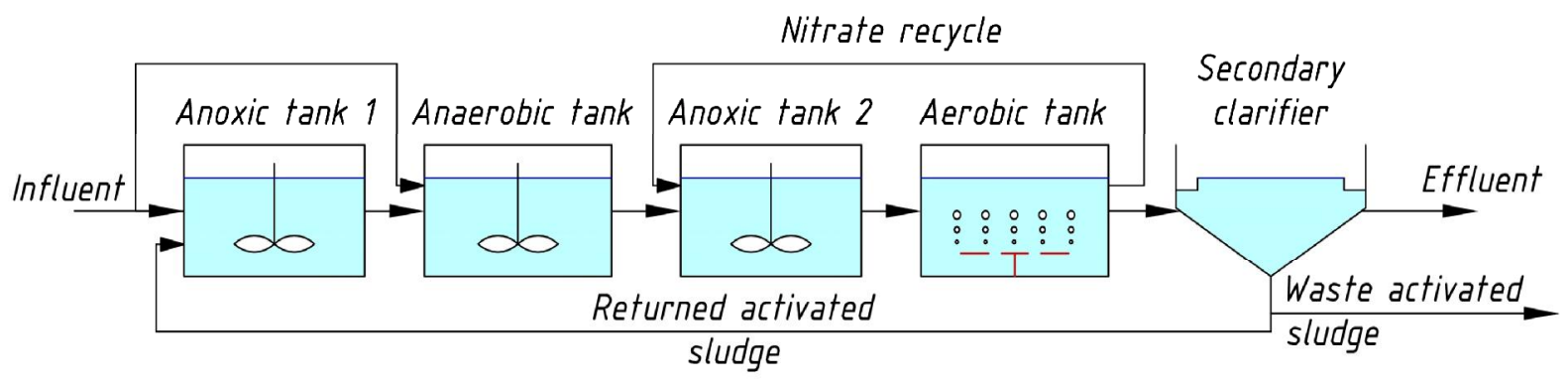

Fig. 7. Technological scheme of the JHB process

In this scheme of the biological treatment process, nitrogen is removed by converting it to a gaseous state, and phosphorus is removed by accumulating its compounds in activated sludge with subsequent removal of its excess from the system (Wiesmann et al., 2007). The advantages of the JHB process are that already partially prodenitrified activated sludge enters the anaerobic zone. This makes biological phosphorus removal more efficient compared to AA/O and Bardenpho processes, but also requires additional volumetric facilities for denitrification of the return activated sludge, which increases the cost of construction and operation.

UCT (University of Cape Town) process scheme. The scheme of the UCT process (Fig. 8) was developed by scientists and engineers at the University of Cape Town (HJ 576-2010, 2010; Wiesmann et al., 2007).

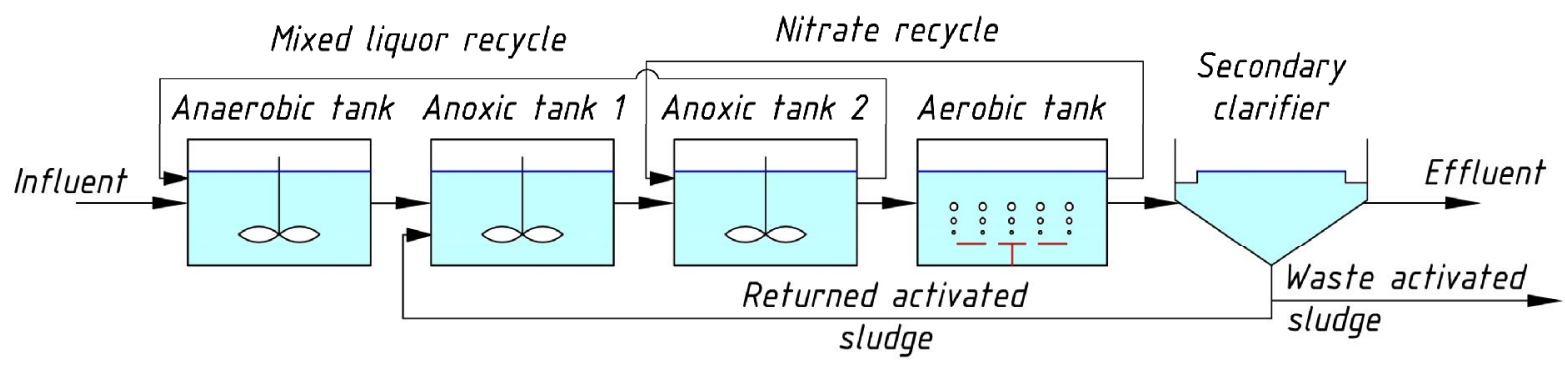

Fig. 8. Technological scheme of the UCT process 
This scheme involves the removal of nitrates from the circulating activated sludge, because in the anaerobic zone there is a mutual inhibitory effect of nitrates and phosphates. The scheme also provides for two stages of recycling of activated sludge. Circulating activated sludge enters the anoxide zone, where partial denitrification takes place. Further, as part of the second stage of recycling, it is pumped into the anaerobic zone. The first stage of the recycle involves the return of nitrates from the aerobic zone to anoxide (Wiesmann et al., 2007).

Due to the entry into the anaerobic zone of prodenitrified sludge mixture, the UCT scheme provides high efficiency and stability of the process of biological treatment of wastewater from phosphorus. However, such a scheme is quite difficult to construction and technological operation.

Modified UCT process scheme. The scheme of the UCT process was improved by dividing the anoxide zone into two separate parts. Thus, a scheme of the modified UCT process was obtained (Fig. 9).

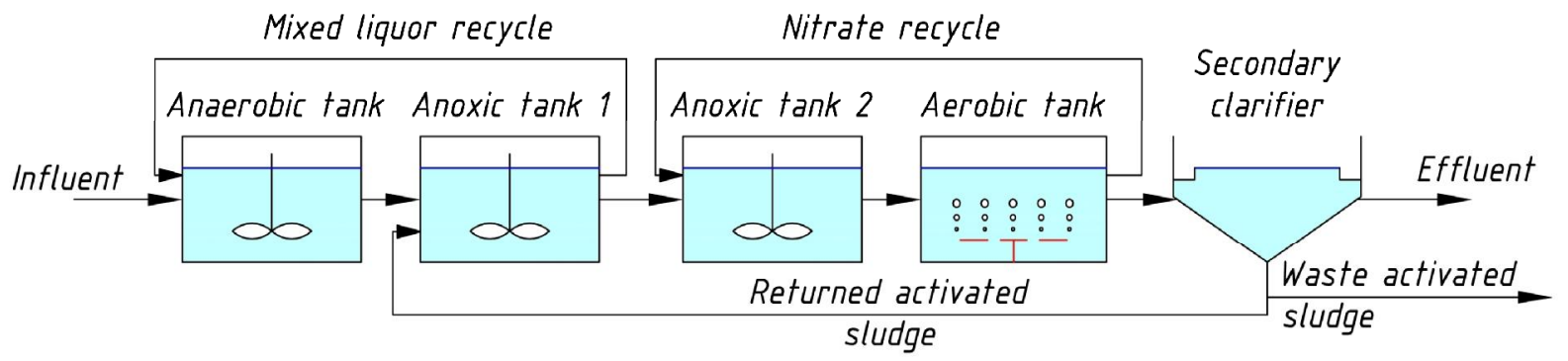

Fig. 9. Technological scheme of the modified UCT process

According to the scheme, the circulating activated sludge is fed to the first anoxide zone for its denitrification. Subsequently, the denitrified activated sludge is pumped to the anaerobic zone, where phosphorus is released without the inhibitory effect of nitrates. In the second anoxide zone, nitrites and nitrates contained in the activated sludge, which enters this zone from the aerobic part, are removed (Vaiopoulou \& Aivasidis, 2008).

The scheme of the modified UCT process provides high efficiency and stability of biological nitrogen removal, including on low-concentrated wastewaters, however as well as the scheme of the UCT process, it is rather difficult in construction and operation.

Phoredoxmodification process scheme. Another interesting scheme of is the scheme of Phoredoxmodification process (Fig. 10).

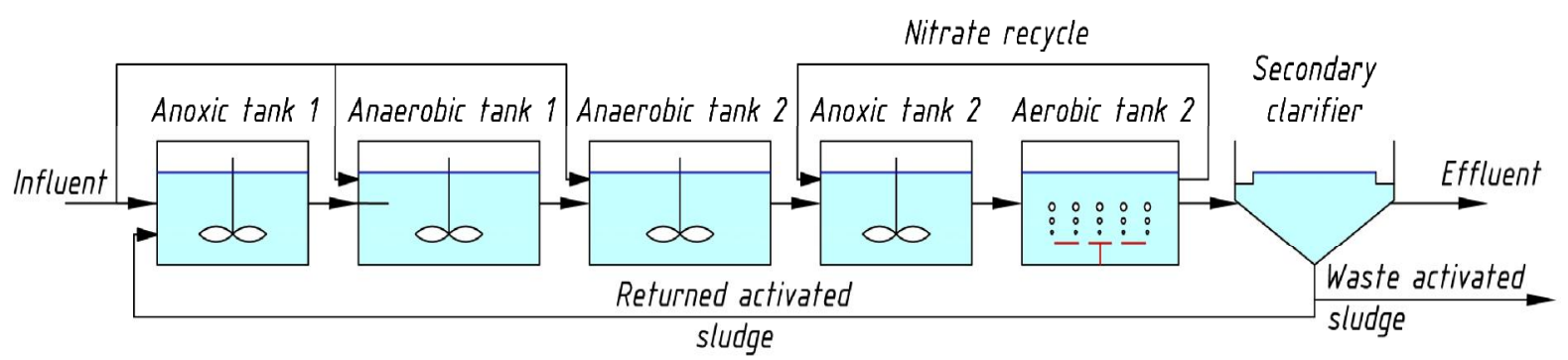

Fig. 10. Technological scheme of the Phoredoxmodification process

It can be considered a slightly more flexible modification of the AA/O scheme. Wastewater entering biological treatment is partially distributed between the first three zones of this scheme. In the first (anoxide) zone the process of partial reduction of nitrates takes place. In the second (anaerobic) zone, part of the nitrates remaining after the first zone is restored, creating conditions close to anaerobic conditions. In the third (anaerobic) zone the process of deep displacement of phosphorus takes place. As a result of the treatment process, the effect of wastewater treatment from phosphorus can reach $95 \%$.

"Uni" process scheme. The technological scheme of biological removal of nitrogen and phosphorus compounds from wastewater "Uni" of the Denifo process (Feofanov, 2019) is shown in Fig. 11. It is recommended for newly created waste water treatment plants, as it is a more flexible adaptive scheme. 


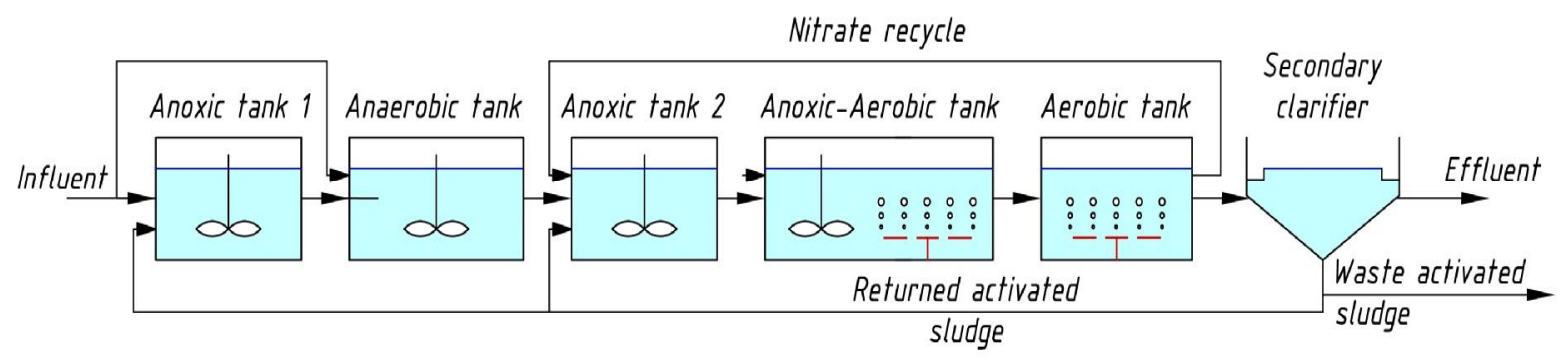

Fig. 11. Universal scheme "Uni" of the Denifo process

This technological scheme allows to achieve a reduction in the concentration of total nitrogen to $8-10 \mathrm{mg} / \mathrm{l}$, ammonium nitrogen to $0.3-0.5 \mathrm{mg} / \mathrm{l}$ and total phosphorus to $0.8-1.5 \mathrm{mg} / \mathrm{l}$.

The final choice of the scheme is made on the basis of technical and economic comparison of different options.

\section{Presenting main material}

Based on the analysis of existing nitridenitrification technologies for complex deep purification of wastewater from organic and biogenic contaminants at Kolomyia treatment plants in Ivano-Frankivsk region, it was proposed to introduce biotechnology of nitridenitrification, which is implemented in biological treatment facilities by alternating anoxide and aerobic zones and using a combination of suspended and immobilized cultures of microorganisms in the aeration zone of aeration tanks (Option I).

The technology has two circuits for sludge recirculation: one external - from the secondary clarifier tank to the anoxide zone, and one internal - from the aerobic zone to the anoxide zone.

As an option for technical and economic comparison of the feasibility of the proposed biotechnology selected biotechnology nitridenitrification with suspended activated sludge, which is implemented in bioremediation facilities by alternating anaerobic, anoxide and aerobic zones (analog of the VIP process), and which provides the same purification quality of wastewater (Option II).

The technology has three sludge recirculation circuits: one external - from the secondary clarifier tank to the anoxide zone, and two internal - from the aerobic zone to the anoxide zone and from the anoxide zone to the anaerobic zone.

The main variable parameters for comparing the two options for biotechnology purification of wastewater are presented in Table 1.

Table 1

Final indicators of the sizes of the constructions necessary for realization of complex biotechnology of sewage treatment on KOS in Kolomyia of the Ivano-Frankivsk region at their reconstruction according to Options I and II

\begin{tabular}{|l|c|c|c|}
\hline \multirow{2}{*}{ Name } & \multicolumn{2}{|c|}{ Complex of biological treatment facilities } & \multicolumn{2}{c|}{$\begin{array}{c}\text { The total cost of } \\
\text { reconstruction by } \\
\text { options, thousand UAH, } \\
\text { including VAT }\end{array}$} \\
\cline { 2 - 4 } & $\begin{array}{c}\text { Aeration tanks Required } \\
\text { volume, } \mathrm{m}^{3} / \text { number of } \\
\text { sections }\end{array}$ & $\begin{array}{c}\text { Secondary clarifier tanks } \\
\text { Required area, } \mathrm{m}^{2} / \\
\text { number of units }\end{array}$ & \multirow{2}{*}{$\begin{array}{c}16117,200 \\
\text { (according to the } \\
\text { project) }\end{array}$} \\
\hline $\begin{array}{l}\text { Option I } \\
\text { Nitridenitrification technology with a } \\
\text { combination in the aeration zone of } \\
\text { suspended and attached biocenoses } \\
\text { and two recirculation circuits }\end{array}$ & $3363 * / 2$ & $452 / 4$ & 34479,550 \\
\hline $\begin{array}{l}\text { Option II } \\
\text { Nitridenitrification technology with } \\
\text { suspended biocenosis and three } \\
\text { recirculation circuits }\end{array}$ & $3363 * / 4$ & & \\
\hline
\end{tabular}

$*$ The actual volume of one section of the aerotank is $W_{f 1}=3363 \mathrm{~m}^{3}$. 
According to Option I, the first corridor of the aeration tank functions as an anoxide zone with the placement of mixer there, and the second, third and fourth corridors operate in aerobic mode with the placement of bioloading there. Coefficient of internal recirculation is equal to $K_{2}=0.7$.

According to Option II, the first corridor of the aeration tank functions as an anaerobic zone with mixer, the second corridor of the aeration tank functions as an anoxide zone also with mixer there, and the third and fourth corridors operate in aerobic mode. The coefficients of internal recirculation are equal to $K_{2}=1.0, K_{3}=0.6$.

Analysis of the results obtained under Option I and II and existing technological schemes of nitridenitrification (AA/O, UCT, Bardenpho, Ludczak-Ettinger, etc.), as well as domestic experience in this area and regulatory recommendations (DBN V.2.5-75:2013, 2013) showed that for the conditions of wastewater treatment plants in Kolomyia, the most appropriate is the introduction of a modified LudczakEttinger process. This process involves the alternation of anoxide and aerobic zones and the use in aeration zones of a combination of suspended and immobilized on inert media cultures of microorganisms. The combination of suspended and immobilized on biocarriers microbial cenoses is necessary for the maintenance in active tanks of active biomaterial taking into account features of character of pollution of entrance wastewaters.

For this purpose, the project proposes the re-equipment of single-corridor aeration tanks located in two blocks of tanks into bioreactors of nitridenitrifiers by creating zones with different oxygen conditions in their volume.

Wastewater after the primary settling tanks and circulating activated sludge will enter the first anoxide zone of the bioreactor, which will be equipped with mixer.

The second zone of the bioreactor will perform the function of aerobic and, accordingly, is equipped with modern aeration and mass transfer systems.

In aerobic zones, a combination of suspended and attached to an inert load biocenosis is used.

Internal recirculation of the sludge-water mixture from the end of the aerobic zone to the beginning of the anoxide zone is provided with the help of modern energy-saving pumps. Coefficient of internal recirculation is equal to $K=0.7$.

The presence in the biosystem of zones with a deficiency of oxygen and the formation of nitrate nitrogen in these zones, in connection with the course of denitrification processes, leads to a decrease in the specific consumption of air oxygen for the processes of biodegradation of pollution and contributes to a reduction in the growth of excess sludge.

Carrying out the process of nitridenitrification in the combination in the aeration zone of aeration tanks suspended and immobilized on inert plastic media cultures of microorganisms, contributes to the intensification of nitridenitrification processes, reducing the volume of structures, further reducing specific air consumption and excess growth. turn, also causes a reduction in energy consumption.

As is known, biotechnology with immobilization of the microflora provides (Zhu, 2007):

- increase of capacity of biological treatment facilities by $100 \%$; the possibility of efficient flow in one volume of both biodegradation processes of organic pollutants (including difficult to oxidize) and processes of nitridenitrification and biological removal of phosphorus compounds, due to the high concentration of biomass, long generation time (age), and different oxygen conditions in the thickness of the attached biological film;

- improvement of sedimentation characteristics of sludge and minimization of its "swelling" phenomena;

- reduction of biomass growth due to the formation in the biosystem of a complete trophic series of microorganisms with ordered food chains, which causes due to the synergistic effect of their activity reduction of sludge growth by $30 \%$ compared to traditional, and causes, accordingly, reduced loads on secondary settling tanks;

- increasing the efficiency of oxygen transfer due to the presence of biofilm carriers in the aeration zone; pollutants.

- constancy of the process to variable hydraulic loads and loads on the concentration of 


\section{Conclusions}

1. The main factors influencing the efficiency of the nitrification process in aeration tanks are: temperature, dissolved oxygen concentration, $\mathrm{pH}$, presence or absence of inhibitory substances.

2. The main factors influencing the efficiency of the denitrification process in aeration tanks: temperature, $\mathrm{pH}$ of the medium, the amount of organic compounds, the concentration of dissolved oxygen in the anoxide zone.

3. Available scientific information shows the prospects and feasibility of using for wastewater treatment methods of step-by-step biological treatment. However, for the practical implementation of this technology it is necessary to conduct special research aimed at creating an effective technology for biological treatment of urban wastewater, fully taking into account the peculiarities of natural and anthropogenic conditions.

4. The most effective and currently used schemes for biological removal of nitrogen and phosphorus are: AA/O process, Bardenpho process, UCT process, MUCT process, Ludzak-Ettinger process. The main advantages of multistage systems are high quality of purified water, deep removal of suspended solids, high oxidizing power, which allow to intensify the processes of nitrification and denitrification.

5. The choice of a specific scheme for the removal of nitrogen and phosphorus for implementation in aeration tanks depends primarily on the quality of the incoming biological wastewater treatment and the requirements for the quality of treated water.

\section{References}

Blyashyna M., Zhukova V., Sabliy L. (2018). Processes of biological wastewater treatment for nitrogen, phosphorus removal by immobilized microorganisms. Eastern-European Journal of Enterprise Technologies. 2. 3037. https://doi.org 10.15587/1729-4061.2018.127058

Shved, O. M., Petrina, R. O., Karpenko, Ya., Novikov, V. P. (2014). Cuchasni tekhnolohii vyluchennia azotu zi stichnykh vod. Biotechnologia Acta, 5, pp. 108-113. doi: 10.15407/biotech7.05.108

Kartik Chandran, Barth, F. Smets. (2005). Optimizing experimental design to estimate ammonia and nitrite oxidation biokinetic parameters from batch respirograms. Water Research, 39(20), pp. 4969-4978. https://doi.org/ 10.1016/j.watres.2005.10.001

Akın \& Ugurlu. (2003). Biological Removal of Carbon, Nitrogen, and Phosphorus in a Sequencing Batch Reactor. Journal of environmental science and health. Part A, Toxic/hazardous substances \& environmental engineering, 38, pp. 1479-88. DOI: 10.1081 / ESE-120021473

Peng, Y.Y., He, S., Wu, F. (2021). Biochemical processes mediated by iron-based materials in water treatement: Enhancing nitrogen and phosphorus removal in low $\mathrm{C} / \mathrm{N}$ ratio wastewater. Science of The Total Environment, Volume 775, 145137. https://doi.org/10.1016/j.scitotenv.2021.145137

Wu, H., Wang, J., Chen, J., Wang, X., Li, D., Hou, J., He, X. (2021). Advanced nitrogen and phosphorus removal by combining endogenous denitrification and denitrifying dephosphatation in constructed wetlands. Journal of Environmental Management, Volume 294, 112967. https://doi.org/10.1016/j.jenvman.2021.112967

Henze, M., George, A., Ekama, Mark C. M. van Loosdrecht, Damir Brdjanovic. (2008). Biological Wastewater Treatment. Principles, Modeling and Design. IWA Publishing, 511 p. https://doi.org/10.2166/ 9781780401867

Vendramelli R., Vijay S., Yuan Q. (2017). Mechanism of nitrogen removal in wastewater lagoon: a case study, Environmental Technology, 38:12, 1514-1523, https://doi.org/10.1080/09593330.2016.1235232

Sedlak R. (2018). Phosphorus and Nitrogen Removal from Municipal Wastewater: Principles and Practice. (2nd ed.), Routledge, 256 p. DOI:10.1201/9780203743546

Xu, S., Bernards, M., Hu, Z. (2014). Evaluation of Anaerobic/Anoxic/Oxic (A2/O) and Reverse A2/O Processes in Biological Nutrient Removal. Water Environment Research, 86, pp. 2186-2193. https://doi.org/86. $10.2175 / 106143014 X 14062131178394$.

Xie, B., Liu, B., Yi, Y., Yang, L., Liang, D., Zhu, Y., \& Liu, H. (2016). Microbiological mechanism of the improved nitrogen and phosphorus removal by embedding microbial fuel cell in Anaerobic-Anoxic-Oxic wastewater treatment process. Bioresource Technology, 207, 109-117. https://doi.org/10.1016/j.biortech.2016.01.090

Technical Specifications for Anaerobic-Anoxic-Oxic Activated Sludge Process (HJ 576-2010). Environmental Protection Industry Standard. China Environmental Protection Industry Association (Water Pollution Control Committee), 2010. http://english.mee.gov.cn/Resources/standards/others1/Specifications_Engineering/201102/ t20110216_200788.shtml 
Dursun, D., Jimenez, J., \& Briggs, A. (2012). Comparison of Process Alternatives for Enhanced Nutrient Removal: Perspectives on Energy Requirements and Costs. Proceedings of the Water Environment Federation, (17), pp. 529-540. DOI: 10.2175 / 193864712811740828

Banayan Esfahani E., Asadi F., Bazargan A., McKay G. (2019). The Modified Bardenpho Process. Springer International Publishing AG, Handbook of Environmental Materials Management, 50 p. https://doi.org/10.1007/ 978-3-319-58538-3_87-1

Udo Wiesmann, In Su Choi, Eva-Maria Dombrowski. (2007). Fundamentals of Biological Wastewater Treatment. Wiley-VCH Verlag GmbH \& Co. KGaA, Weinheim, 391 p. DOI:10.1002/9783527609604.

Vaiopoulou, Eleni \& Aivasidis, Alexander. (2008). A modified UCT method for biological nutrient removal: Configuration and performance. Chemosphere, 72, 1062-8. https://doi.org/10.1016/j.chemosphere.2008.04.044

Feofanov, Yu. A. (2019). Rol retsirkulyatsii zhidkosti pri rabote sooruzheniy biologicheskoy ochistki stochnyih vod. Voda i ekologiya: problemyi i resheniya, 4, pp. 79-87. https://doi.org 10.23968/2305-3488.2019. 24.4.79-87

Zhu Y. (2007)/ Immobilized Cell Fermentation for Production of Chemicals and Fuels. Bioprocessing for Value-Added Products from Renewable Resources, New Technologies and Applications. 373-396 https://doi.org/ 10.1016/B978-044452114-9/50015-3

І. Ю. Попадюк, І. І. Матлай, Б. С. Піцишин, Т. А. Сидор Національний університет “Львівська політехніка”, кафедра гідротехніки та водної інженерії

\title{
ІННОВАЦІЙНИЙ МЕТОД НІТРИФІКАЦІЇ ТА ДЕНІТРИФІКАЦІЇ НА ПРИКЛАДІ КАНАЛІЗАЦЙНИХ ОЧИСНИХ СПОРУД М. КОЛОМИЯ
}

\author{
(C) Попадюк I. Ю., Матлай I. І., Піиишин Б. С., Сидор Т. А., 2021
}

Велика кількість каналізаційних очисних споруд України стикається з незадовільною роботою споруд біологічного очищення стічних вод. Основним заходом щодо підвищення якості очищення на очисних спорудах $\epsilon$ переведення їх на технології видалення азоту і фосфору. В Україні відсутні сертифіковані схеми видалення біогенних елементів. На прикладі очисних споруд м. Коломия ІваноФранківської обл. показано один з варіантів вирішення цієї проблеми.

Комунальні стічні води м. Коломиї за ступенем забрудненості за БСК 20 і завислим речовинам належать до низькоконцентрованих.

На основі аналізу наявних у світовій практиці технологічних схем нітри-, денітрифікації, вітчизняного досвіду в цій галузі та нормативних рекомендацій показав, що для умов КОС в м. Коломия, найдоцільніше впроваджувати модифікований процес Людчака-Етінгера, що реалізується в спорудах біоочистки через чергування аноксидної та аеробних зон та із застосуванням у зонах аерації комбінації завислих і іммобілізованих на інертних носіях культур мікроорганізмів (комбінація завислих і іммобілізованих на біоносіях мікробних ценозів необхідна для утримання в аеротенках активного біоматеріалу з урахуванням особливостей характеру забрудненості вхідних стічних вод).

Для цього пропонують переобладнати однокоридорні аеротенки, що розташовані в складі двох блоків ємностей, як біореактори нітри-, денітрифікатори за допомогою створення в їхньому об'ємі зон із різними кисневими умовами.

Стічні води після первинних відстійників і циркуляційний активний мул будуть надходити в першу аноксидну зону біореактора, що буде обладнана мішалками.

Друга зона біореактора виконуватиме функцію аеробної і, відповідно із цим, обладнується сучасними системами аерації та масообміну.

В аеробних зонах використовується комбінація завислого та прикріпленого на інертному завантаженні біоценозу.

Ключові слова: стічні води, аеротенк, нітрифікація, денітрифікація, вторинний відстійник, активний мул. 